Dhaka Univ. J. Biol. Sci. 19(2): 145-150, 2010 (July)

\title{
BACTERIAL LOAD IN TWELVE FRESHWATER FISHES OF FOUR FEEDING HABITS IN BANGLADESH
}

\author{
M. SHAMSUR RAHMAN ${ }^{1}$, MAHMUd HASAN ${ }^{1}$, Zahid Hayat MAHMUd \\ AND M. SIRAJUL ISLAM* \\ International Centre for Diarrhoeal Disease Research, Bangladesh (ICDDR,B), \\ Mohakhali, Dhaka, Bangladesh
}

Key words: Bacterial load, Freshwater fishes, Feeding habit

\begin{abstract}
Homogenized samples of skin, gill and gut of twelve freshwater fishes of four feeding habits were used for bacteriological test. Total bacterial count (TBC), total coliform (TC), faecal coliform (FC), faecal streptococci (FS) and total Vibrio-like colonies were enumerated using serial dilution and spread plate techniques. Variation of bacterial loads among the fishes of various feeding habits was insignificant. The TBC, TC, FC, FS and total Vibrio counts ranged from $1.72 \pm 0.68 \times 10^{8}$ to $7.00 \pm 3.39 \times 10^{8}, 2.49 \pm 1.72 \times 10^{6}$ to $6.55 \pm 3.00 \times 10^{6}, 1.58$ $\pm 1.29 \times 10^{6}$ to $2.76 \pm 1.42 \times 10^{6}, 4.83 \pm 2.09 \times 10^{4}$ to $1.19 \pm 0.46 \times 10^{5}$ and $2.06 \pm 0.67$ $\times 10^{3}$ to $3.68 \pm 2.02 \times 10^{5}$, respectively among various feeding groups. However, gill and gut had significantly higher density of TBC, TC and FC than that of the skin. High counts of indicator organisms indicate that market fishes of all varieties could be the potential reservoirs in transmission of pathogenic bacteria responsible for diarrhoeal disease.
\end{abstract}

\section{Introduction}

Bacterial decomposition has been shown to be a major factor causing rapid deterioration of fish quality.(1) Shewan ${ }^{(2)}$ suggested that the bacterial flora on fish reflects the aquatic environment which affects the quality and storage life of fishery products. The quality of fish can be assessed by the degree of contamination with coliform bacteria. Contamination results mainly from rupturing of fish intestine during poor processing or unhealthy washing. Several studies have suggested that intestinal microflora or contamination of fish as a result of enteric bacteria of human or animal origin are responsible for food spoilages.(3) Considerable interest has been given in studying the occurrence and distribution of the various bacterial pollution indicators in the water and the associated environment. It has been suggested repeatedly that the bacterial flora of fish might reflect the bacteriological conditions of the water and a potential indicator of pollution. Coliforms, fecal coliforms, and fecal streptococci are not normal inhabitants of the gut of fish and have a short, unaltered survival in their intestinal tract.

*Corresponding author: <sislam@icddrb.org>. 'Department of Fisheries, University of Dhaka, Dhaka-1000, Bangladesh. 
In Bangladesh, every day 20,000 metric tons of human excreta are deposited on public lands and waterways and is one of the main causes of contamination of surface water. ${ }^{(4)}$ During the time of rainy season the fecal matters of various sources are washed away from the contaminated land and are ultimately carried into different water bodies (e.g. ponds, rivers, lakes etc.). Moreover, due to the poor sanitary condition of the country most of the latrines in rural settings are directly connected to the natural water reservoirs. Thus, virtually all the aquatic habitats of Bangladesh are heavily contaminated with fecal coliform bacteria. Fishes which live in these polluted habitats thus can easily intake these bacteria while feeding along with contaminated aquatic foods.

On the other hand, fish taken from estuarine waters or rivers, ponds, lakes and canals may carry pathogenic bacteria such as Salmonella spp., Shigella spp., Vibrio cholerae and other water borne pathogens. Fish of good quality should have counts of total bacteria less than $10^{5}$ per gram and faecal coliforms, staphylococci should not exceed 10/g and $100 / \mathrm{g}$, respectively.(5)

Migration of the bacteria from water to fish may cause spoilage of fish and out break of disease. The aim of the present study is to determine the bacterial load in different organs of fishes of different feeding habits to understand the microbiological status of the aquatic environment.

\section{Materials and Methods}

Twelve fishes of four feeding habits viz., herbivores, carnivores, detrivores and omnivores were examined each with three replicates. The fishes were identified and grouped following $\operatorname{Kumar}^{(6)}$, Rahman(7), Shafi and Quddus( ${ }^{(8)}$, Mustafa et al. ${ }^{(9)}$ and Nargis and Hossain.(10) The samples were collected from Anand Bazar, Shoarighat and Mohakhali bazar fish markets of Dhaka city. The samples were transported to the laboratory using sterilized polythene bags in icebox $\left(<5^{\circ} \mathrm{C}\right)$ within two hours of sampling in the morning and processed within $2-4 \mathrm{hr}$ of collection following aseptic techniques. First, the samples were washed with sterile phosphate buffer saline (PBS) to remove sand, detritus as well as microorganisms attached to the surface of fish. After washing the skin, gill and gut were separated aseptically. The fish parts were separately homogenized with sterile PBS solution using homogenizer and were then used for bacteriological analysis.

Spread plate method was used to enumerate the total bacteria as described by Hasan and Bart(11) using dehydrated nutrient agar (Oxoid, USA) medium. For the enumeration of total and fecal coliform, $100 \mu \mathrm{l}$ sample was serially diluted and spreaded on the $\mathrm{mFC}$ plate. Incubation was carried out for $24 \mathrm{hr}$ at $37^{\circ} \mathrm{C}$ for total coliform and at 44 to $44.5^{\circ} \mathrm{C}$ for fecal coliform. Fecal Streptococci (FS) were enumerated on KFSA plate, which was incubated at $37^{\circ} \mathrm{C}$ for $48 \mathrm{hr}$. After $48 \mathrm{hr}$ incubation pink colonies were selected for 
counting of FS. Total Vibrio-like colonies was counted on TCBS plate. Colonies of yellow and green color after 18 - $24 \mathrm{hr}$ of incubation were counted as Vibrio-like organism.

\section{Results and Discussion}

Raw fishes are highly perishable protein source that contain normal bacterial flora from their environments in addition to the contaminants occurred during harvesting and handling of the products. The living fishes carry populations of predominantly Gramnegative psychrotrophic bacteria on their external skin, nearly $10^{2}-10^{3}$ bacteria per gram. Coliforms could be absent or present in very low density and Salmonella, Shigella, Vibrio and other enteric pathogens are usually not found as these organisms are not the normal flora of the fishes or of their environment.(5) However, in the present study the fish samples of different feeding habits were found highly contaminated with total aerobic bacteria as well as total coliform, fecal coliform and fecal streptococci (Table 1). This might be due to the contamination of source water from where the fishes were caught or might be due to secondary contamination during the time of handling as well as storage of fishes in ice made with contaminated water.

Table 1. Bacterial density (cfu/g) measured in different fishes of four different feeding habits.

\begin{tabular}{|c|c|c|c|c|c|}
\hline \multirow{2}{*}{$\begin{array}{l}\text { Feeding } \\
\text { habit }\end{array}$} & \multicolumn{5}{|c|}{ Bacterial load (cfu/g) } \\
\hline & TBC & $\mathrm{TC}$ & $\mathrm{FC}$ & FS & $\begin{array}{l}\text { Total Vibrio -like } \\
\text { colonies on TCBS }\end{array}$ \\
\hline Herbivorous & $2.91 \pm 1.59 \times 10^{8}$ & $4.52 \pm 3.39 \times 10^{6}$ & $1.58 \pm 1.29 \times 10^{6}$ & $5.20 \pm 2.10 \times 10^{4}$ & $8.50 \pm 4.71 \times 10^{3}$ \\
\hline Carnivorous & $5.05 \pm 2.37 \times 10^{8}$ & $4.68 \pm 1.69 \times 10^{6}$ & $2.50 \pm 1.19 \times 10^{6}$ & $8.99 \pm 2.97 \times 10^{4}$ & $2.06 \pm 0.67 \times 10^{3}$ \\
\hline Detrivorous & $7.00 \pm 3.39 \times 10^{8}$ & $6.55 \pm 3.00 \times 10^{6}$ & $2.76 \pm 1.42 \times 10^{6}$ & $1.19 \pm 0.46 \times 10^{5}$ & $3.68 \pm 2.02 \times 10^{5}$ \\
\hline Omnivorous & $1.72 \pm 0.68 \times 10^{8}$ & $2.49 \pm 1.72 \times 10^{6}$ & $1.75 \pm 1.24 \times 10^{6}$ & $4.83 \pm 2.09 \times 10^{4}$ & $7.36 \pm 3.10 \times 10^{3}$ \\
\hline
\end{tabular}

$\mathrm{TBC}=$ Total bacterial count; $\mathrm{TC}=$ Total coliform count $\mathrm{FC}=$ Fecal coliform count; FS = Fecal streptococcal count Means $( \pm$ SEM) within column and row for total of each parameter of bacterial density without letters denote no significant differences (ANOVA, HSD, $\mathrm{p}<0.05$ ).

There was no remarkable variation of total bacterial count, total coliform count, fecal coliform count, fecal streptococcus count and total Vibrio-like count among the different groups of feeding habits of the fishes.

TBC and FC counts of the various kinds of fishes were more or less similar while the TC, FS and total Vibrio counts varied considerably among the different fish samples (Table 2). The TC counts varied between $5.14 \pm 4.37 \times 10^{5}$ in hilsa and $1.08 \pm 0.43 \times 10^{7}$ in boal. All the fish samples showed high counts of fecal coliform (FC) (ranged between 4.16 $\pm 2.29 \times 10^{4}$ in shol and $5.91 \pm 3.96 \times 10^{6}$ in common carp) and fecal streptococci (ranged between $1.33 \pm 1.08 \times 10^{4}$ in hilsa and $1.97 \pm 1.18 \times 10^{5}$ in common carp). 
Likewise, common carp had significantly higher density of total Vibrio-like colonies than in silver carp and hilsa. The densities of total Vibrio-like colonies on TCBS found in other fishes were not different from those of silver carp, hilsa and common carp.

Comparing the bacterial counts in the fish organs, gill and gut showed significantly higher density of TBC, TC and FC than that of the skin (Table 3). However, the density of FS found in the gill was the highest while the lowest density was observed on the skin. The density of FS measured in the gut was not different from gill and gut.

Table 2. Bacterial density (cfu/g) measured in different fishes sampled from different markets of Dhaka metropolis.

\begin{tabular}{lccccc}
\hline Fish & \multicolumn{5}{c}{ Bacterial load (cfu/g) } \\
\cline { 2 - 6 } & TBC & TC & FC & FS & $\begin{array}{c}\text { Total Vibrio-like } \\
\text { colonies on TCBS }\end{array}$ \\
\hline Silver carp & $1.23 \pm 1.01 \times 10^{8}$ & $4.34 \pm 2.21 \times 10^{5 \mathrm{ab}}$ & $2.43 \pm 1.09 \times 10^{5}$ & $1.77 \pm 0.56 \times 10^{4 \mathrm{ab}}$ & $6.67 \pm 3.73 \times 10^{1 \mathrm{~b}}$ \\
Catla & $2.36 \pm 1.14 \times 10^{8}$ & $2.38 \pm 1.05 \times 10^{6 \mathrm{ab}}$ & $4.84 \pm 3.55 \times 10^{5}$ & $1.05 \pm 0.57 \times 10^{5 \mathrm{a}}$ & $1.19 \pm 0.55 \times 10^{3 \mathrm{ab}}$ \\
Thai pangus & $5.13 \pm 4.61 \times 10^{8}$ & $1.07 \pm 1.02 \times 10^{7 \mathrm{ab}}$ & $4.02 \pm 3.87 \times 10^{6}$ & $3.28 \pm 2.12 \times 10^{4 \mathrm{ab}}$ & $2.42 \pm 1.30 \times 10^{4 \mathrm{ab}}$ \\
Shol & $1.21 \pm 0.58 \times 10^{8}$ & $2.70 \pm 1.23 \times 10^{5 \mathrm{ab}}$ & $4.16 \pm 2.29 \times 10^{4}$ & $6.65 \pm 4.39 \times 10^{4 \mathrm{ab}}$ & $3.12 \pm 1.73 \times 10^{3 \mathrm{ab}}$ \\
Boal & $1.07 \pm 0.68 \times 10^{9}$ & $1.08 \pm 0.43 \times 10^{7 \mathrm{a}}$ & $5.77 \pm 3.32 \times 10^{6}$ & $6.59 \pm 3.60 \times 10^{4 \mathrm{ab}}$ & $2.03 \pm 0.99 \times 10^{3 \mathrm{ab}}$ \\
Meni & $3.21 \pm 1.38 \times 10^{8}$ & $3.00 \pm 1.46 \times 10^{6 \mathrm{ab}}$ & $1.69 \pm 0.77 \times 10^{6}$ & $1.37 \pm 0.70 \times 10^{5 \mathrm{ab}}$ & $1.03 \pm 0.41 \times 10^{3 \mathrm{ab}}$ \\
Mrigal & $9.00 \pm 8.63 \times 10^{8}$ & $9.28 \pm 6.68 \times 10^{6 \mathrm{ab}}$ & $1.88 \pm 1.37 \times 10^{6}$ & $6.42 \pm 3.13 \times 10^{4 \mathrm{ab}}$ & $4.09 \pm 2.58 \times 10^{3 \mathrm{ab}}$ \\
Common & $1.12 \pm 0.55 \times 10^{9}$ & $9.37 \pm 6.08 \times 10^{6 \mathrm{ab}}$ & $5.91 \pm 3.96 \times 10^{6}$ & $1.97 \pm 1.18 \times 10^{5 \mathrm{ab}}$ & $1.10 \pm 0.55 \times 10^{6 \mathrm{a}}$ \\
carp & & & & & \\
Rohu & $7.45 \pm 3.65 \times 10^{7}$ & $9.98 \pm 4.69 \times 10^{5 \mathrm{ab}}$ & $5.00 \pm 2.14 \times 10^{5}$ & $9.49 \pm 7.00 \times 10^{4 \mathrm{ab}}$ & $3.62 \pm 1.57 \times 10^{3 \mathrm{ab}}$ \\
Koi & $2.76 \pm 1.94 \times 10^{8}$ & $6.74 \pm 5.03 \times 10^{6 \mathrm{ab}}$ & $4.69 \pm 3.63 \times 10^{6}$ & $1.10 \pm 0.57 \times 10^{5 \mathrm{ab}}$ & $1.83 \pm 0.82 \times 10^{4 \mathrm{ab}}$ \\
Tilapia & $1.33 \pm 0.57 \times 10^{8}$ & $2.27 \pm 1.00 \times 10^{5 \mathrm{ab}}$ & $1.21 \pm 0.66 \times 10^{5}$ & $2.14 \pm 1.11 \times 10^{4 \mathrm{~b}}$ & $3.19 \pm 1.70 \times 10^{3 \mathrm{ab}}$ \\
Hilsa & $1.07 \pm 0.43 \times 10^{8}$ & $5.14 \pm 4.37 \times 10^{5 \mathrm{~b}}$ & $4.39 \pm 3.96 \times 10^{5}$ & $1.33 \pm 1.08 \times 10^{4 \mathrm{~b}}$ & $6.00 \pm 5.13 \times 10^{2 \mathrm{~b}}$ \\
\hline
\end{tabular}

$\mathrm{TBC}=$ Total bacterial count; $\mathrm{TC}=$ Total coliform count; FC $=$ Fecal coliform count; FS $=$ Fecal streptococcal count Means $( \pm$ SEM) within column with different letters are significantly different (ANOVA, HSD; $p<0.05$ ).

Table 3. Bacterial density (cfu/g) measured in different organs of fishes sampled from different markets of Dhaka metropolis.

\begin{tabular}{lccccc}
\hline \multirow{2}{*}{$\begin{array}{l}\text { Organs } \\
\text { of } \\
\text { fishes }\end{array}$} & TBC & TC & FC & FS & $\begin{array}{c}\text { Total Vibrio-like } \\
\text { colonies on TCBS }\end{array}$ \\
\cline { 2 - 6 } & $1.37 \pm 0.41 \times 10^{7 \mathrm{~b}}$ & $1.58 \pm 0.70 \times 10^{5 \mathrm{~b}}$ & $8.49 \pm 4.53 \times 10^{4 \mathrm{~b}}$ & $2.87 \pm 1.40 \times 10^{4 \mathrm{~b}}$ & $2.72 \pm 2.33 \times 10^{3}$ \\
\hline Skin & $5.91 \pm 2.21 \times 10^{8 \mathrm{a}}$ & $8.04 \pm 3.01 \times 10^{6 \mathrm{a}}$ & $3.83 \pm 1.46 \times 10^{6 \mathrm{a}}$ & $1.74 \pm .40 \times 10^{5 \mathrm{a}}$ & $8.93 \pm 7.75 \times 10^{4}$ \\
Gill & $6.46 \pm 2.45 \times 10^{8 \mathrm{a}}$ & $5.49 \pm 2.20 \times 10^{6 \mathrm{a}}$ & $2.54 \pm 1.17 \times 10^{6 \mathrm{a}}$ & $2.93 \pm 0.75 \times 10^{4 \mathrm{ab}}$ & $1.98 \pm 1.35 \times 10^{5}$ \\
Gut & 6
\end{tabular}

$\mathrm{TBC}=$ Total bacterial count; $\mathrm{TC}=$ Total coliform count; FC $=$ Fecal coliform count; FS = Fecal streptococcal count Means $( \pm$ SEM) within column with different letters are significantly different (ANOVA, HSD, $p<0.05$ ). 
Coliform, faecal coliform and faecal streptococci count of the fishes of different feeding habitats examined in this study exceeded the acceptable limit recommended by Food and Agricultural Organization. ${ }^{(5)}$ This indicates that freshwater fishes collected from pond, river, lake and canal etc. are potential sources of disease causing organisms. Therefore, precautions should be taken to prevent contamination during harvesting as well as post harvest handling of fishes. Depending on the habitat and other environmental factors, a wide range of variation in distribution of microflora in fish has been reported.(2) The present study agrees with these findings.

According to the guideline of ICMSF, ${ }^{(12)}$ acceptable limit of total bacterial counts for giant prawns and white fish are $10^{6}$ and $5 \times 10^{5} \mathrm{cfu} / \mathrm{g}$, respectively. Total coliform, faecal coliform, and Vibrio cholerae counts are 102, 10 and $0 \mathrm{cfu} / \mathrm{g}$, respectively, for both the types of fish. Therefore, the bacterial loads (total bacteria, total coliform, faecal coliform and Vibrio) found in this study for different fishes were beyond the standard value suggested by ICMSF, which indicate their unacceptability as food from public health point of view. The occurrence of fecal coliform in fish could be a reflection of the pollution level of their water environment in addition to their feeding habits. It has been suggested repeatedly that the bacterial flora of fish might reflect the bacteriological conditions of the water and thus be a potential indicator of pollution. ${ }^{(3)}$ Gibbons $^{(13)}$ studied on fish caught from the marine environment and concluded that coliform bacteria are not usually associated with the normal intestinal flora of fish. However, organisms of the coliform and streptrococcal groups have been isolated from various species of freshwater fish caught in relatively clean to moderately polluted waters in India ${ }^{(14)}$, Norway ${ }^{(15)}$, Canada ${ }^{(16)}$, United States ${ }^{(17)}$ etc. Margolis ${ }^{(16)}$ reported that the bacterial flora of freshwater fish depends solely upon the fish's recent intake of food and the degree of contamination in the food and water.

The abundance of indicator bacteria as well as high bacterial load in the fish samples of different feeding habits indicates a possibility of future outbreak of pathogenic diseases through ingestion of contaminated fish including chances of cross contamination via kitchen utensils or by handling. The presence of high bacterial load in the fish samples may indicate fecally contaminated water sources and also poor hygienic practices by fisherman. Hence, the data might be of help in assessing human health risk due to consumption of freshwater fishes of different feeding habits. Indeed, care should be taken for long-term monitoring programme for potentially pathogenic bacteria in freshwater fishes.

\section{References}

1. Laycock RA and LW Regier 1971. Trimethylamine producing bacteria on haddock (Melanogrammus aeglefinus) fillets during refrigerated storage. J. Fish Res. Bd. Can. 28: 305.

2. Shewan JM 1976. The bacteriology of fresh and spoiling fish and the biochemical changes induce by bacterial action. In: Proceeding of tropical institute conference on the handling, processing and marketing of tropical fish. Tropical Products Institute, London, pp. 51-66. 
3. Geldreich EE and NA Clarke 1966. Bacterial pollution indicators in the intestinal tract of freshwater fish. Appl. Microbiol. 14: 429-437.

4. GoB (Government of Bangldesh) 2003. Water sanitation and hygiene promotion. A national strategy for economic growth, poverty reduction and social development. Presented to the GED, planning commission, 5 March 2003, Government of Bangladesh.

5. FAO (Food and Agricultural Organization) 1979. Manuals of food quality control: 4. microbiological analysis. FAO Food and Nutrition paper 14/4.

6. Kumar D 1992. Fish culture in undrainable ponds - A manual for extension. FAO Fisheries technical paper No. 325. FAO (Food and Agricultural Organization of United Nations), Rome, p. 239.

7. Rahman AKM 2005. Freshwater Fishes of Bangladesh, (2 ${ }^{\text {nd }}$ ed)., Zoological Society of Bangladesh, Dhaka, Bangladesh, 28; p. 394.

8. Shafi M and MMA Quddus 2001. Bangladesher matsho shampad (Fisheries of Bangladesh). Kabir Publications, Dhaka.

9. Mustafa G, ATA Ahmed and KR Islam 1980. Food, Feeding habits and fecundity of a freshwater perch, menifish. J. Agri. Bangladesh. 5: 205-210.

10. Nargis A and MA Hossain 1987. Food and feeding habit of koi fish (Anabas testudineus Bloch). Bangladesh. J. Agri. 12: 121-127.

11. Hasan M and AN Bart 2007. Improved survival of rohu, Labeo rohita (Hamilton-Buchanan) and silver carp, Hypophthalmichthys molitrix (Valenciennes) fingerlings using low-dose quinaldine and benzocaine during transport. Aquacult. Res. 38: 50-58.

12. ICMSF 1982. Microorganisms in food. Vol. 2, Sampling for microbiological analysis: principles and specific applications. International Commission on the Microbiological Specification of Foods (ICMSF). Univ. Toronto Press, Toronto.

13. Gibbons NE 1934. The slime and intestinal flora of some marine fishes. Contrib. Can. Biol. Fisheries (N.S.) 8: 275-290.

14. Venkataraman $R$ and A Sreenivasan 1953. The bacteriology of freshwater fish. Indian J. Med. Res. 41: 385-392.

15. Thjqtta T and OM Somme 1943. The bacterial flora of normal fish. Skrifter Norske VidenskapsAkad. Oslo Mat. Naturv. 4: 1-86.

16. Margolis L 1935. The effect of fasting on the bacterial flora of the intestine of fish. J. Fisheries Res. Board Can. 10: 62-63.

17. Johnson GA 1904. Isolation of Bacillus coli communis from the alimentary tract of fish and the significance thereof. J. Infect. Diseases 1: 348-354. 